\title{
Impact of Workers' Remittances on Economic Growth: An Empirical Study of Pakistan's Economy
}

\author{
Waqas Bin Dilshad ${ }^{1,2}$ \\ ${ }^{1}$ Research Scholar, Bahria University Karachi, Pakistan \\ ${ }^{2}$ Visiting Lecturer National University of Modern Languages, Karachi, Pakistan \\ Correspondence: Waqas Bin Dilshad, House no R-599, Sector-8, North Karachi, Karachi, 75850, Pakistan. Tel: \\ 92-0300-273-0242 or 92-0345-319-4663. E-mail: link2waqas@gmail.com
}

Received: October 8, 2013

Accepted: October 31, 2013 Online Published: November 18, 2013

doi:10.5539/ijbm.v8n24p126

URL: http://dx.doi.org/10.5539/ijbm.v8n24p126

\begin{abstract}
Pakistan like other developing countries in the world is known for its high migration and workers' remittance. In general it is considered that workers' remittances are the important source for external finance and economic growth but many studies conducted on the same topic revealed some positive, negative and neutral responses of workers' remittances toward economic growth. It is also argued that the high migration rate in any country represents the poor economic conditions of that country. This study identifies the impact of workers' remittances on economic growth of Pakistan by analyzing time series data of twenty two years from 1991 to 2012 . Regression model has been used to identify the relationship between the variables. The results conclude that there exist a significant positive relationship between workers' remittances and economic growth in Pakistan and it has been recommended for policy implication that Pakistan should encourage and motivate the flow of workers' remittances and adopt such policies that insist remitter to send money through proper channels so that these flows can be utilized in a better way for economic growth and development.
\end{abstract}

Keywords: GDP, economic growth, workers’ remittances, Pakistan

\section{Introduction}

Workers' remittances are the cash inflows coming from foreign countries as a result of foreign workers' remitting or transferring money to their home. These cash inflows have been increasing rapidly in developing countries. The history of transferring money by foreign workers to their home is very significant and cannot be overlooked as these remittances have impact on economic growth. A number of studies have been conducted just to identify the impact of workers' remittances on economy and still there is a mix opinion about the relationship of workers' remittances and economic growth.

Workers' remittances as compare to other external inflows are more important and playing important role in economic growth they are considered more extensive because of the stability in nature. Vogiazides (2008) Workers' Remittances affect economy in developing countries but remittances are not the strategy for sustainable development because most of the remittances are spent on consumption rather on saving and investment therefore government should break the cycle of dependence on remittance for growth and development. Jawaid and Raza (2012) Workers' remittances can be utilized efficiently to ensure economic growth. Waheed and Aleem (2008) Workers' remittances and cash inflows are good only for short period for long term economic growth countries should increase exports instead of workers' remittances.

Pakistan like other developing countries in the world is known for its high migration and workers' remittance. It is argued that this high migration is the result of poor economic conditions of the country because the economy is facing so many problems like unemployment, illiteracy, poverty, inflation, and terrorism etc. The people of Pakistan are migrating to foreign countries in search of job and to change their living standards. It is also argued that due to the high level of unemployment individuals are going abroad to get the employment and livelihood for their family and this unemployment is creating the problem of brain drain.

World Bank (2011) Pakistan is the seventh top emigration country with 4.7 million emigrants and eleventh top remittance receiving country with 9.4 billion US\$. Pakistan Economic Survey (2011-2012) Workers' remittances have been important sources of foreign exchange for years and these remittances are not only 
providing support to balance of payment but also helping in poverty reduction and economic growth through different ways.

Keeping in view all the facts, importance and significance of workers' remittances this study will identify the relationship between workers' remittances and economic growth, the impact of workers' remittances on economic growth on Pakistan's economy by analysing time series data of twenty two years (1991 to 2012). This paper consist of seven parts following introduction, part two consist of some theoretical and empirical review of literature, part three consist of problem statement/Research question and objectives, part four consist of modelling framework for estimation, part five consist of results and interpretation of estimation, part six consist of conclusion on the basis of analysis and provides some policy implications, part seven consist of some limitations of the study and also provide some directions for further research.

\section{Review of Literature}

Ratha and Mohapatra, (2007) prepared a note for G8 outreach event on Remittance to indentify the macro economic impact of remittances on development and concluded that remittances are the most important source of finance and in most of the under developed countries they are the biggest source of external financing and they also help in reducing poverty as well as they increase standards of leaving of the people who are receiving the remittance. The effects of remittance on growth are mixed but in the presence of good policy huge remittance can eradicate export competitiveness as well as can play a foreign role in exchange rate.

Jawaid and Raza (2012) examined the data of seven years of 113 countries to determine the association of remittances and economic growth and identified after empirical examination that here exist an important direct relationship linking worker's remittances to economic growth. It was also identified that workers' remittances are contributing more in high income countries.

Irfan (2011) conducted an empirical study on remittances and poverty linkages in Pakistan and after analyzing that data from 1975 to 2009 concluded that GDP is the significant factor with remittance which leads to poverty reduction and economic development.

Wakayama (2011) wrote a thesis on remittance and GDP growth in developing countries and after analyzing the Europe and central Asia region countries concluded that there is no correlation between remittance and GDP per capital growth therefore remittance cannot express GDP correctly in countries whose ratio of remittance to GDP as suggested by core.

Siddique, Selvanathan and Selvanathan (2010) conducted a study on remittance and economic growth on major south Asian countries i.e. Bangladesh, India and Sri Lanka and after empirical analysis identified that remittances have a mixed response with the economic growth. In Bangladesh remittance is not the cause of economic growth and same is the case with India no casual relationship is found between remittance and economic growth but in Sri Lanka a two way casual relationship is found between remittance and economic growth which effects vice-versa.

Karagoz, (2009) conducted a study on the same topic workers' remittance and economic growth with reference to economy of Turkey and after analyzing time series data of thirty five years concluded that workers' remittance have a strong relationship with economic growth and these two variables are negative correlated.

Jawaid and Raza (2012) conducted study on the same topic workers' remittance and economic growth with the view to identify the relationship between these two variables after analyzing the time series data of twenty nine years of China and Korea concluded that workers' remittances have significant relationship with economic growth in china and Korea but that relationship is not same in two countries. Significant positive relationship was found between workers' remittances and economic growth in Korea in long run while significant negative correlation was identified between workers' remittances with economic growth in China.

Giuliano and Ruiz-Arranz (2005) a study conducted by IMF about impact of remittance on growth in which the data of 101 developing countries was analyzed and it was found that there exist no relationship between remittances and growth.

Waheed and Aleem (2008) empirically examined the time series data from 1981 to 2006 of Pakistan's economy with the view to recognize the impact of workers' remittance on economic growth and identified that workers' remittances and economic growth have significant positive linking in short run while negative impact in long run.

Jongwanich, (2007) analyzed the panel data from 1993 to 2003 to indentify the relationship of workers' remittance with poverty and economic growth. Seventeen developing countries of Asia pacific were in the study 
and concluded that workers' remittance have significant direct relationship with economic growth as well as with poverty alleviation.

Iqbal and Sattar (2005) examined the data of Pakistan with the view to answer the question whether workers' remittance contribute to economic growth and determined through empirical analysis of time series data from 1973 to 2003 that workers' remittances are the important source of economic growth in Pakistan.

\section{Problem Statement/Research Question and Objectives}

\section{A. Problem statement}

High migration rate shows the poor economic conditions of a country and this high migration is causing high worker's remittances therefore it in question that are these remittances really causing economic growth.

\section{B. Research Question}

What is the impact of worker's remittances on economic growth in Pakistan?

\section{Research Objectives}

- To identify the relationship between worker's remittances and economic growth.

- To recommend some implications of policy on the basis of analysis.

\section{Modelling Framework}

On the basis of literature review the model to study the impact of workers' remittances on economic growth has been derived from the production function framework. The same model has been drived and used by Waheed and Aleem (2008), Jawaid and Raza (2012), and Iqbal and Sattar (2005). The production framework is:

$$
Y=f(A, L, K)
$$

Here "Y" represents the gross domestic product (GDP); "L" represents the employed labour force; "K" represents the stock of capital and "A" represents the total productivity of economic factors. Impact of workers' remittances can be identified through "A". (Waheed and Aleem, 2008; Jawaid and Raza, 2012)

$$
A=g(W R)
$$

Here "WR" represents workers' remittances. By substituting (2) in (1):

$$
Y=f(L, K, W R)
$$

Through this general production function the empirical model for estimation has been developed as follows:

$$
Y=\beta_{0}+\beta_{1} E L F+\beta_{2} G F C F+\beta_{3} W R+\varepsilon
$$

In the above model Y represents the gross domestic product, $\beta_{1}$ represents employed labour force, $\beta_{2}$ represents gross fixed capital formation as percentage of gross domestic product, $\beta_{3}$ represents the workers' remittances and $\varepsilon$ represents the error term. It is expected that the sign of $\beta_{1} \& \beta_{2}$ are positive although the sign of $\beta_{3}$ will be identified. Yearly time series data of Pakistan from 1991 to 2012 has been used. The data source is economic survey of Pakistan (ministry of finance's website) and handbook of statistics on Pakistan's economy (state bank of Pakistan's website)

The values of gross domestic product (GDP), gross fixed capital formation (GFCF) have been taken in million rupees while the data of workers' remittance (WR) was not available in PKR so its values have been determined by multiplying the workers' remittances data (in USD) with average annual exchange rate of USD and PKR.

\section{Estimation Results}

This study has been conducted with the view to identify the impact of workers' remittances on economic growth. Time series data of twenty two years have been collected from the official sources of Pakistan's economy and analyzed with the help of regression model. Gross domestic product (GDP) has been taken as dependent variable while workers' remittances (WR) employed labour force (ELF) and gross fixed capital formation (GFCF) as independent variable. The results show that there exists a positive relationship between workers' remittances and economic growth. 
Table 1. Descriptive statistics

\begin{tabular}{lcccc}
\hline & GDP & ELF & GFCF & WR \\
\hline Mean & 6337963. & 40988182 & 0.164533 & 251023.9 \\
Median & 4331264. & 38725000 & 0.164792 & 105545.8 \\
Maximum & 20653868 & 55800000 & 0.209226 & 960584.0 \\
Minimum & 1020600. & 29520000 & 0.109222 & 36458.22 \\
Std. Dev. & 5664482. & 8500233. & 0.026351 & 279436.0 \\
Skewness & 1.235930 & 0.413637 & -0.20966 & 1.300519 \\
Kurtosis & 3.476338 & 1.865141 & 2.748086 & 3.470806 \\
Jarque-Bera & 5.808907 & 1.807928 & 0.219345 & 6.404805 \\
Probability & 0.054779 & 0.404961 & 0.896128 & 0.040664 \\
Sum & $1.39 \mathrm{E}+08$ & $9.02 \mathrm{E}+08$ & 3.619733 & 5522525. \\
Sum Sq. Dev. & $6.74 \mathrm{E}+14$ & $1.52 \mathrm{E}+15$ & 0.014582 & $1.64 \mathrm{E}+12$ \\
Observations & 22 & 22 & 22 & 22 \\
\hline
\end{tabular}

Source: Author's Estimation result.

The above table shows the descriptive statistics of all the variables included in the study. We can see the average workers' remittance that is 251023.9 , the maximum and minimum value of remittance during the studied year's i.e. (max. 960584.0 And min. 36458.22), standard deviation of workers' remittances during the studied years (279436.0), and other related descriptive statistics that have been gathered by the estimation results.

Table 2. Correlation matrix

\begin{tabular}{lllll}
\hline & GDP & ELF & GFCF & WR \\
\hline GDP & 1.000000 & 0.948830 & -0.46614 & 0.987373 \\
ELF & 0.948830 & 1.000000 & -0.31897 & 0.924993 \\
GFCF & -0.46614 & -0.31897 & 1.000000 & -0.46677 \\
WR & 0.987373 & 0.924993 & -0.46677 & 1.000000 \\
\hline
\end{tabular}

Source: Author's Estimation result.

The correlation matrix shows the relationship of all the variables with each other. The relationship of employed labour force and economic growth (ELF and GDP) is 0.948 which shows strong positive relationship. The relationship of gross fixed capital formation and economic growth (GFCF and GDP) is - 0.466 moderately negative relationships while the relationship of workers' remittances with economic growth (WR with GDP) is 0.987 which shows strong positive relationship.

Table 3. Results of regression model

\begin{tabular}{|c|c|c|c|c|}
\hline $\begin{array}{l}\text { Dependent Variable: GDP } \\
\text { Method: Least Squares } \\
\text { Sample: } 19912012 \\
\text { Included observations: } 22\end{array}$ & & & & \\
\hline Variable & Coefficient & Std. Error & t-Statistic & Prob. \\
\hline $\mathrm{C}$ & -8795173 & 3155801 & -2.78699 & 0.0122 \\
\hline ELF & 0.194473 & 0.05225 & 3.721948 & 0.0016 \\
\hline LOG(GFCF) & -2021155 & 1187855 & -1.70152 & 0.1061 \\
\hline WR & 13.89642 & 1.735424 & 8.007509 & 0.0000 \\
\hline R-squared & 0.985909 & \multicolumn{2}{|c|}{ Mean dependent var } & 6337963 \\
\hline Adjusted R-squared & 0.98356 & \multicolumn{2}{|c|}{ S.D. dependent var } & 5664482 \\
\hline S.E. of regression & 726288 & \multicolumn{2}{|c|}{ Akaike info criterion } & 29.99225 \\
\hline Sum squared resid & $9.49 \mathrm{E}+12$ & \multicolumn{2}{|c|}{ Schwarz criterion } & 30.19062 \\
\hline Log likelihood & -325.915 & \multicolumn{2}{|c|}{ Hannan-Quinn criter. } & 30.03898 \\
\hline F-statistic & 419.795 & \multicolumn{2}{|c|}{ Durbin-Watson stat } & 1.440709 \\
\hline $\operatorname{Prob}($ F-statistic) & 0.0000 & & & \\
\hline
\end{tabular}


In the above table- 3 the results of regression model has been shown. The model is best fit as the adjusted R square is near 1 (i.e. 0.983 ). The probability of workers' remittances is 0.0000 and the t-statistic shows the positive figure which is grate than two (8.007) so we can easily conclude that workers' remittances have the significant positive relationship with economic growth (GDP).

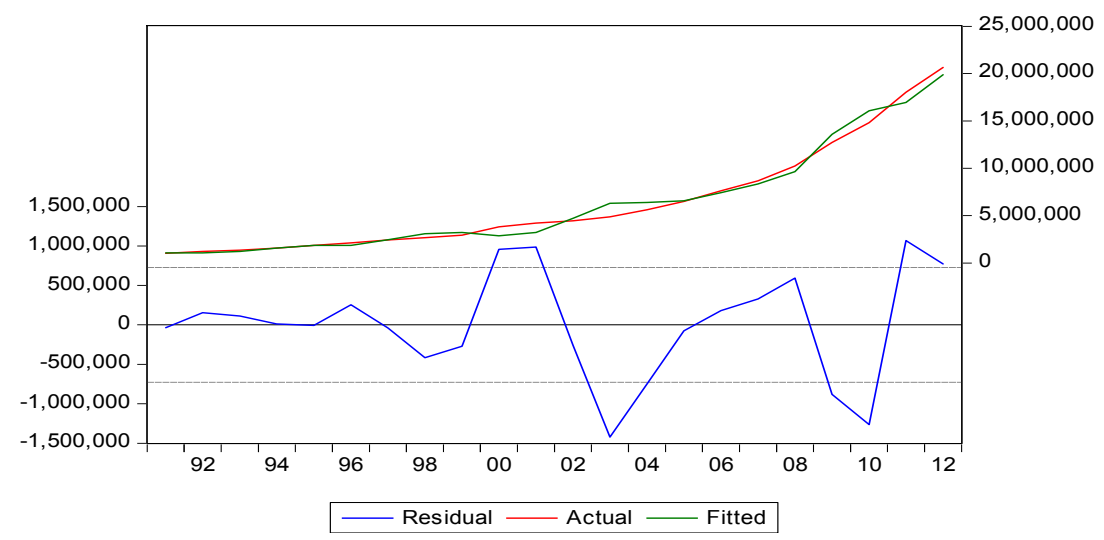

Figure 1. Actual fitted graph

Source: Author's estimation result.

The above actual fitted residual graph shows the fitted values of regression equation indicating that this model explains the data well.

\section{Conclusion and Policy Implications}

In this paper we investigated the impact of workers' remittance on economic growth through time series empirical regression and correlation analysis it is identified that workers' remittances have impact on economic growth in Pakistan and there exist a significant positive relationship between workers' remittances and economic growth in Pakistan. Besides all the negatives of high migration and the factors which are causing high migration like poor economic conditions, unemployment, poverty etc it is recommended that Pakistan should make policies that encourage and motivate the inflow of remittances through proper channel because some remittances are still sent through hundis due to non friendly policies. Pakistan should utilize these inflows of remittances efficiently for economic growth and development. Pakistan should focus on these remittances as these remittances are not only a source of economic growth but also these remittances are reducing poverty as well as these remittances are a major source of foreign exchange and helping to overcome the problem of balance of payment. If these remittances are utilized properly in efficient way these could help in overcoming the problem of brain drain and high migration and the effective utilization of these remittances can help in achieving sustainable development.

\section{Direction for Further Research}

This study has been conducted on time series data of twenty two years only of Pakistan economy by increasing the data (no of years) it can be validated further. A comparative study can also be conducted by using the panel data of the developing countries i.e. Pakistan, India, Bangladesh, Sri Lanka, etc to identify and validate the impact of remittance on economic growth in a broader way. Further studies can be conducted on the impact of workers' remittance on poverty reduction, education, health and living standards to identify the overall importance and significance of workers' remittances.

\section{References}

Giuliano, P., \& Ruiz-Arranz, M. (2005). Remittances, Financial Development and growth. IMF Working Paper, WP/05/234. Retrieved from http://www.imf.org/external/pubs/ft/wp/2005/wp05234.pdf

Iqbal, Z., \& Sattar, A. (2005). The Contribution of Workers' Remittances to Economic Growth in Pakistan. Research Report, ISBN 969-461-126-1, Pakistan institute of development economics. Retrieved from http://www.pide.org.pk/Research/Report187.pdf 
Irfan, M. (2011). Remittances and poverty linkages in Pakistan evidence and some suggestions for further analysis. Working Paper, Pakistan institute of development economics. Retrieved from http://www.pide.org.pk/pdf/Working\%20Paper/WorkingPaper-78.pdf

Jawaid, S. T., \& Raza, S. A. (2012). Workers' remittances and economic growth in China and Korea: an empirical analysis. Journal of Chinese Economic and Foreign Trade Studies, 5(3), 185-193.

Jawaid, S. T., \& Raza, S. A. (2012). Remittances, Growth and Convergence: Evidence from Developed and Developing Countries. University Library of Munich, Germany. Retrieved from http://mpra.ub.uni-muenchen.de/39002/1/MPRA_paper_39002.pdf

Jongwanich, J. (2007). Workers' remittances, economic growth and poverty in developing Asia and the Pacific countries. UNESCAP Working Papers No. WP/07/01. Retrieved from http://www.unescap.org/pdd/publications/workingpaper/wp_07_01.pdf

Karagoz, K. (2009). Workers' remittances and economic growth: evidence from Turkey. Journal of Yasar University, 4(13), 1891-908. Retrieved from http://journal.yasar.edu.tr/wp content/uploads/2012/05/no13_vol4_01_karagoz.pdf

Pakistan Economic Survey. (2011-2012). Chapter-1. Growth and Stabilization. Retrieved from http://www.finance.gov.pk/survey/chapter_12/01-GrowthAndStabilization.pdf

Ratha, D., \& Mohapatra, S. (2007). Increasing Marco Economic Impact of Remittances on Development (Development Prospect Group The World Bank). Retrieved from http://dilipratha.com/index_files/G8Berlin.pdf

Siddique, A., Selvanathan, E. A., \& Selvanathan, S. (2010). Remittances and Economic Growth: Empirical Evidence from Bangladesh, India and Sri Lanka (discussion paper). The University of Western Australia, Retrieved from http://www.uwa.edu.au/_data/assets/pdf_file/0006/1371948/10-27-Remittances-andEconomic-Growth.pdf

UN. (2011). Impact of remittances in poverty in developing countries. United Nations conference on trade and development. Retrieved from http://unctad.org/en/Docs/ditctncd20108_en.pdf

Vogiazides, L. (2008). Migrant Workers' remittances: A Development Instrument in question. European Social Watch Report. Retrieved from http://www.socialwatch.eu/2009/documents/remittances.pdf

Waheed, A., \& Aleem, A. (2008). Workers' remittances and economic growth: empirical evidence from Pakistan. Journal of Social Science and Humanities, 47(1), 1-12.

Wakayama, Y. (2011). Can remittances be the source of GDP growth in developing countries? (Bachelor Thesis). Tokyo University of Foreign Studies. Retrieved from http://www.tufs.ac.jp/insidetufs/kyoumu/doc/yusyu22_wakayama.pdf

\section{Copyrights}

Copyright for this article is retained by the author(s), with first publication rights granted to the journal.

This is an open-access article distributed under the terms and conditions of the Creative Commons Attribution license (http://creativecommons.org/licenses/by/3.0/). 